\title{
Overview of linguistic annotation
}

Linguistic examples quoted in the chapters are given interlinear glosses and English translations. The glossing conventions followed here are laid out in the following sections.

\section{Glossing of Old Irish examples}

Nouns are glossed with their translational equivalent and followed by the case (NOM, ACC, GEN, DAT) in subscript small capitals. Singular number is viewed here as default and is not glossed. Plural nouns are glossed with the tag ${ }_{\text {pL}}$, added after the case abbreviation following a full stop (е.g. мом.P.).
(1) feraib
men $_{\text {DAT.PL }}$
(2) geinti
gentiles $_{\text {NOM.PL }}$

Adjectives are glossed with their translational equivalent and followed by case, number $\left({ }_{\mathrm{SG}}\right.$, PL $)$, and gender $\left({ }_{\mathrm{MASC}},{ }_{\mathrm{FEM}},{ }_{\mathrm{NEUT}}\right)$ in subscript small capitals, each tag separated by a full stop.
(3) móir
$\operatorname{big}_{\text {ACC.SG.FEM }}$

The definite article and other prenominal modifiers (such as quantifiers) are, generally speaking, glossed in the same way as an adjective. However, when the definite article is found immediately before a stressed demonstrative, no gender features are tagged since the demonstrative itself lacks clearly discernible gender features.
(4)
a. in
fer
b. in
the $\mathrm{NOM} . \mathrm{SG} . \mathrm{MASC} \operatorname{man}_{\mathrm{NOM}}$
the NOM.SG $_{\text {. }}$
this $_{\mathrm{NOM}}$
só 
The unstressed demonstrative particles, -sin distal ('that') and -so proximal ('this') are glossed respectively as DIST and PROX. These tags are attached to the preceding item with the equals sign. Stressed demonstratives are tagged as nouns, as in (4b) above.
a. in
fer-sin

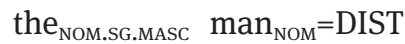
b. in
fer-so
the NOM.SG.MASC $_{\operatorname{man}_{\mathrm{NOM}}}=\mathrm{PROX}$

The stressed anaphoric pronoun, suide (in all case forms) is glossed with the tag ANAPH followed by case and number tags in subscript capitals with full stops between each tag type. Note that, as with nouns, singular is default and is not tagged. The unstressed anaphoric particle, which has the forms side, sidi, ade, de, adi, di, is only glossed with the tag ANAPH.
(6) a. trisodin
through=ANAPH ${ }_{\mathrm{ACC}}$
b. achotlud adi
his $=$ sleep $_{\text {Nom }}$ ANAPH

Prepositional pronouns are glossed with the translational equivalent of the basic preposition followed by tags for person, number, gender, and case (in that order) in subscript small capitals. Tags for gender and case are separated from the tags for person and number with a full stop. The case tag is only used to disambiguate between the two possible cases (accusative and dative) governed a subset of prepositions which can govern both of these cases. If the preposition only ever governs one case, the case is not indicated in the glossing.
(7) a. dóib
to $_{3 \mathrm{PL}}$
b. foir
on $_{\text {3SG.MASC.ACC }}$
c. for
on $_{3 S G . M A S C . D A T}$

Verbs are glossed with their translational equivalent and followed by abbreviations in subscript small capitals for agreement, tense, mood, passive and relative (in that order) with a full stop between each abbreviation. The abbreviations 
used are listed in (8). Note that indicative mood is here conceived of as the default and is not glossed.

(8) a. Tense: ${ }_{\text {PRES }}$ (present), ${ }_{\text {IMPF }}$ (imperfect), ${ }_{\text {PST }}$ (past, only in past subjunctive), ${ }_{\text {PRET }}$ (preterite), ${ }_{\text {FUT }}$ (future).

b. Mood: ${ }_{\text {subj }}$ (subjunctive), ${ }_{\text {CND }}$ (conditional), ${ }_{\text {IMPV }}$ (imperative).

c. Passive forms are tagged ${ }_{\mathrm{PASS}}$; relative forms are tagged ${ }_{\mathrm{REL}}$.

d. Agreement: ${ }_{1 \mathrm{SG}},{ }_{2 \mathrm{SG}}$, 3SG, 1PL, 2PL, 3PL.

e. The augment is tagged AUG or ${ }_{\text {AUG }}$ (see below).

The sequence of glosses in verbs and examples of the method of glossing is given in (9). AUG has two positions. If it is the first preverb in the verbal complex it is treated as a PV (see below), consider (9a). If it is not the first preverb in verbal complex, it is glossed as in (9c).

(9) a. ro.berthae
AUG.bring 3 3SG.PST.SUBJ.PASS
b. berthar
bring $_{3 \text { SG.PRES.SUBJ.PASS.REL }}$
c. inroigrainn
PV·persecute AUG.3SG.PRET $_{\text {P }}$

For compound verbs, the lexical preverb is glossed separately as PV in capitals. Preverbs are separated from verbal roots by a raised dot in the glossing, even when the dot does not appear in the quoted example. Where present, infixed pronouns (glossed as 1SG, 2SG, 3SG $\mathrm{MASC}_{\mathrm{MS}}$, 3SG $\mathrm{FEM}_{\mathrm{FEM}}$, 3SG $\mathrm{SGEUT}_{\mathrm{NET}}$, 1PL, 2PL, 3PL) are inserted after the PV (or AUG) after a hyphen. If relevant the class type is added in pa-

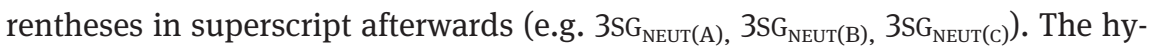
phen is also used for the infixed relative, which is glossed REL, in prepositional relatives at after the preverbs imm and $a$.

Consonant mutations play an important role in all Insular Celtic languages. In Od Irish, there are two prominent ones: lenition and nasalization. Lenition causes an initial stop to become a fricative; nasalisation causes initial voiceless stops to become voiced and prefixes a homorganic nasal to initial voiced stops and vowels. The mutations are glossed as superscript ${ }^{\text {LEN }}$ and ${ }^{\mathrm{NAS}}$ respectively before the mutated form. Examples that follow these rules are given in (10).

$$
\begin{aligned}
& \text { a. as beir } \\
& \mathrm{PV} \cdot \text { say }_{3 \mathrm{SG} . \mathrm{PRES}}
\end{aligned}
$$


b. at.beir

$\mathrm{PV}-3 \mathrm{SG}_{\mathrm{NEUT}} \cdot \mathrm{Say}_{3 \mathrm{SG} . \mathrm{PRES}}$

c. as.mbeir

PV. ${ }^{\text {NAS }}{ }_{\text {Say }}$ 3SG.PRES

d. rondasaibset

AUG ${ }^{{ }^{N A S}}{ }^{3 S_{\text {FEM }}} \cdot$ pervert $_{3 \text { PL.PRET }}$

e. immetét

PV-REL-surround ${ }_{3 S G . P R E S}$

Old Irish possesses a series of pronominal clitics that serve, roughly speaking, to emphasise items to which they cliticise. In traditional Irish grammar, these are called notae augentes. They are glossed with $1 \mathrm{SG}, 2 \mathrm{SG}, 3 \mathrm{SG}_{\mathrm{MASC}}, 3 \mathrm{SG}_{\mathrm{FEM}}$, $3 \mathrm{SG}_{\mathrm{NEUT}}$, 1PL, 2PL, 3PL. These abbreviations are not in super/subscript. They are separated from the glosses for the stressed word with an equal sign (=) as in (11); see also below.

(11) as $\cdot$ beir $=$ som
$\mathrm{PV} \cdot \mathrm{Say}_{3 \mathrm{SG} . \mathrm{PRES}}=3 \mathrm{SG}_{\mathrm{MASC} / \mathrm{NEUT}}$

The example itself is presented using the editorial conventions of the edition cited. For example, if the edition does not use a raised dot to separate preverb from root, or a hyphen or equals sign to separate a nota augens from the verb, these are not inserted into the main text of the example. Punctuation is only inserted into the gloss as in (12).

(12) asbeirsom

$\mathrm{PV} \cdot$ say $_{3 \mathrm{SG} . \mathrm{PRES}}=3 \mathrm{SG}_{\mathrm{MASC} / \mathrm{NEUT}}$

In the gloss, an equal sign is used to separate an unstressed element from a stressed element (13), when the two are not separated by a space in the edition cited. A hyphen is used to separate an unstressed element from another unstressed element (14). A period is inserted between the words of translational equivalents where these consist of two or more words (15). An underscore is used between two possibly stressed items that are written without separation in the example (16).

(13) isuidiu in $=\mathrm{ANAPH}_{\mathrm{DAT}}$ 
(14) a. arní

for-NEG

b. donaibferaib

for-the DAT.PL.MASC $=$ men $_{\text {DAT.PL. }}$

(15) mórabba

great.cause $_{\mathrm{ACC}}$

(16) ísíu

DEICT_this $\mathrm{DAT}_{\text {D }}$

Note that (16) shows that the deictic particle 1 is glossed as DEICT. The negative particles are glossed NEG (main clause ní), NEGsuB (non-main clause na/nach/ nad) in subordinate non-relative clauses and NEGREL in relative clauses.

\section{Glossing of Brittonic examples}

The glossing of Brittonic examples is somewhat different from the glossing of Old Irish. These differences are exemplified below.

Nouns and adjectives are glossed with their translational equivalent only. ${ }^{1}$

(17) a. gwin

wine

b. riuedi

numbers

(18) margh uskis

horse swift

The definite article is glossed as DEF.

(19) 'r llys

DEF court

1 Very occasionally, subscript small capital ${ }_{\mathrm{PL}}$ is used to disambiguate a plural form of an adjective from a non-plural form (e.g. Welsh eraill is glossed other ${ }_{\mathrm{PL}}$ ). Certain numerals have feminine and masculine forms. These are distinguished with subscript small capital ${ }_{\mathrm{FEM}}$ and $_{\text {MASC, }}$, (e.g. tri three $\mathrm{MASC}_{\mathrm{VS}}$ tair three $\mathrm{FEM}_{\mathrm{F}}$ ). 
All pronouns in Brittonic are tagged with the appropriate agreement tag (1SG, 2SG, 3SG, 1PL, 2PL, 3PL) and, if necessary, the following tags in subscript capitals:

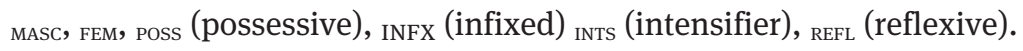

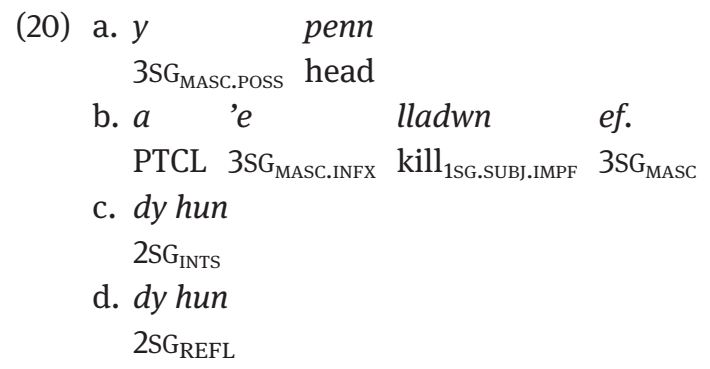

All demonstratives in Brittonic are tagged as either DIST (distal) or PROX (proximal).

(21) a. henna

DIST

b. an den ma

DEF man PROX

c. hynny

PROX

Verbs are glossed with their translational equivalent and followed by abbreviations in subscript small capitals for agreement, tense, mood, and impersonal (in that order) with a full stop between each abbreviation. The abbreviations used are listed in (22). Note that indicative mood is here conceived of as the default and is not glossed.

(22) a. Agreement: ${ }_{1 \mathrm{SG}}, 2 \mathrm{SG}, 3 \mathrm{SG},{ }_{1 \mathrm{PL}}, \mathrm{PL}_{\mathrm{PL}}, 3 \mathrm{PL}$.

b. Tense: ${ }_{\text {PRES }}$ (present), ${ }_{\text {PRET }}$ (preterite), ${ }_{\text {FUT }}$ (future), ${ }_{\text {IMPF }}$ (imperfect), ${ }_{\text {PLPF }}$ (pluperfect), нав (habitual).

c. Mood: suBJ (subjunctive), coND (conditional), ${ }_{\text {IMPV }}$ (imperative).

d. IMPS (impersonal)

e. The perfective particle $r e, r y$, ' $r$ (etc.) is tagged PERF.

The sequence of glosses in verbs and examples of the method of glossing is given in (23). 
(23) a. ledy

kill $_{\text {2SG.PRES }}$

b. deuthant

come $_{3 \text { PL.PRET }}$

c. lladwn

kill $_{1 \mathrm{SG.IMPF.SUBJ}}$

d. wnathoed

$\mathrm{do}_{3 \mathrm{SG} . \text { PLPF }}$

e. bythynt

be 3 РL.НАв

The particle ym- (also spelled em-) is glossed PV. This is separated from verbal roots by a raised dot in the glossing. Infixed pronouns (glossed as $1 \mathrm{SG}_{\mathrm{INF}}$, etc.) are separated from the verb and supporting particles by whitespace. Examples that follow these rules are given in (24).

(24) a. ym.dodant

$$
\text { PV·melt } 3 \text { PL.PRES }
$$

b. re gowsys

PERF·speak 3 SG.PRET

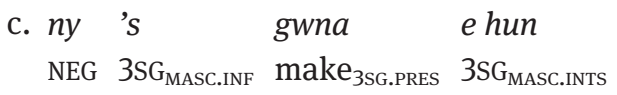

Other verb-related glosses are: vN (verbal noun), PST-PTCPL (past participle), PTCPL (participle), all subscript small capitals.

Negative particles are glossed NEG, with subscript SUB used for the subordinate negative, where necessary. The predicative particle ( $y n$ in Welsh) is glossed PRED. The progressive particle (ow in Cornish) is glossed PROG. Other particles are glossed PTCL.

\section{List of abbreviations}

$\begin{array}{ll}1 & \text { 1st person } \\ 2 & \text { 2nd person } \\ 3 & \text { 3rd person } \\ \text { A } & \text { Class A pronouns } \\ \text { ACC } & \text { Accusative } \\ \text { ANAPH } & \text { Anaphor } \\ \text { AUG } & \text { Augment } \\ \text { B } & \text { Class B pronouns }\end{array}$




$\begin{array}{ll}\text { C } & \text { Class C pronouns } \\ \text { CND } & \text { Conditional } \\ \text { DAT } & \text { Dative } \\ \text { DEF } & \text { Definite } \\ \text { DEICT } & \text { Deictic particle í } \\ \text { DIST } & \text { Distal Demonstrative } \\ \text { FEM } & \text { Feminine } \\ \text { FUT } & \text { Future } \\ \text { GEN } & \text { Genitive } \\ \text { HAB } & \text { habitual } \\ \text { IMPF } & \text { Imperfect } \\ \text { IMPS } & \text { Impersonal } \\ \text { IMPV } & \text { Imperative } \\ \text { INF } & \text { Infinitive } \\ \text { INFX } & \text { Infix } \\ \text { INTS } & \text { Intensifier } \\ \text { LEN } & \text { Lenitition } \\ \text { MASC } & \text { Masculine } \\ \text { NAS } & \text { Nasalization } \\ \text { NEG } & \text { Negation } \\ \text { NEUT } & \text { Neuter } \\ \text { NOM } & \text { Nominative } \\ \text { PASS } & \text { Passive } \\ \text { PERF } & \text { Perfect } \\ \text { PL } & \text { Plural } \\ \text { PLPF } & \text { Pluperfect } \\ \text { POSS } & \text { Possessive } \\ \text { PRED } & \text { Predicative Particle } \\ \text { PRES } & \text { Present } \\ \text { PRET } & \text { Preterite } \\ \text { PROG } & \text { Progressive } \\ \text { PROX } & \text { Proximal Demonstrative } \\ \text { PST } & \text { Past (Subjunctive) } \\ \text { PST-PTCPL } & \text { Past passive participle } \\ \text { PTCPL } & \text { Participle } \\ \text { PV } & \text { Preverb } \\ \text { REFL } & \text { Reflexive } \\ \text { REL } & \text { Relative } \\ \text { SG } & \text { Singular } \\ \text { SUB } & \text { Subordinate (Negative) } \\ \text { SUBJ } & \text { Subjunctive } \\ \text { VN } & \text { Verbal Noun } \\ & \\ \text { INT }\end{array}$

